\title{
Co-existing mafic and felsic magmas in the early Proterozoic rapakivi granite suite of Southern Greenland
}

\author{
T. N. HARRISON, R. J. REAVY, A. A. FINCH and P. E. BROWN
}

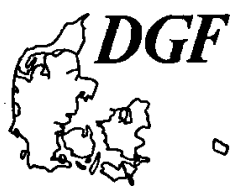

\begin{abstract}
Harrison, T. N., Reavy, R. J., Finch A. A. and Brown, P. E.: Co-existing maficand felsic magmas in the early Proterozoic rapakivi granite suite of southern Greenland. Bull. geol. Soc. Denmark, vol. 38 p. 53-58, Copenhagen, April 25th, 1990. https://doi.org/10.37570/bgsd-1990-38-05

The early Proterozoic rapakivi granites of Southern Greenland often contain synplutonic mafic intrusions in the form of dyke complexes or plug-like bodies. They often display crenulate chilled contacts with their host and the two have not mixed to any degree. This lack of mixing can be attributed to strong viscosity, temperature and density contrasts between the two magma types, despite their similar mass fractions. During the emplacement of the mafic intrusions the host magma had a crystal content greater than $60 \%$ and consequently convective mixing was negligible.
\end{abstract}

T. N. Harrison and P. E. Brown, Department of Geology, Marischal College, Aberdeen University, Aberdeen AB9 $1 A S, U . K$.

R. J. Reavy, Department of Earth Sciences, Liverpool University, PO Box 147, Liverpool L69 3BX, U.K. A. A. Finch, Grant Institute of Geology, University of Edinburgh, West Mains Road, Edinburgh EH9, 3JW, U.K. February 28th, 1989.

\section{Introduction}

The rapakivi suite of Southern Greenland comprises a large number of late- to post-orogenic mafic and felsic plutons emplaced between c. 1780-1740 Ma into a thick series of early Proterozoic migmatitic metasediments and metavolcanics of upper amphibolite to lower granulite metamorphic facies (reviewed by Allaart 1976). Bridgwater et al. (1974) suggested that the rapakivi granites were emplaced by the ductile collapse, or downfolding, of the country rock during the intrusion of the magma. However, Hutton et al. (in prep.) have suggested that emplacement was largely controlled by crustal-scale extensional shear zones.

The mafic plutons are dominantly monzonorites and mela-monzonites although rare monzogabbros and peridotites also occur. The felsic plutons (the "rapakivi granites") are a series of monzonites and quartz-poor granodiorites characterised by abundant, large K-feldspar ovoids (generally comprising $30-60 \%$ of the rock and often up to $10 \mathrm{~cm}$ across) which frequently develop rapakivi texture (the mantling of $\mathrm{K}$-feldspar with a rim of plagioclase). In the subsequent text, the field terms "norite" and "rapakivi gran- ite" are used to describe all mafic and felsic plutonic rocks unless otherwise specified. The larger mafic plutons are earlier than the felsic plutons, and both show a close spatial association (Bridgwater 1963).

Evidence for magma mingling and localised mixing is often compelling in the rapakivi granites, and Bridgwater (1963) described synplutonic mafic intrusions from the Sydprøven rapakivi granite (not shown on fig. 1 ; lies at $46^{\circ} 30^{\prime} \mathrm{W}$ $60^{\circ} 20^{\prime} \mathrm{N}$ ). In addition, there are several other localities where coexisting mafic and felsic magmas have been observed by the present authors in the rapakivi granites; these are shown on figure 1.

\section{Prins Christians Sund}

The most spectacular development of synplutonic mafic intrusions is in the Prins Christians Sund pluton, where a large number of NNW-SSE striking sub-parallel synplutonic dykes are seen in the granite. In addition, the dykes cut a zone of pervasive magma mixing which is developed within the pluton. Many of the dykes are composite felsic-mafic intrusions and can be traced along strike for up to $4 \mathrm{~km}$. 


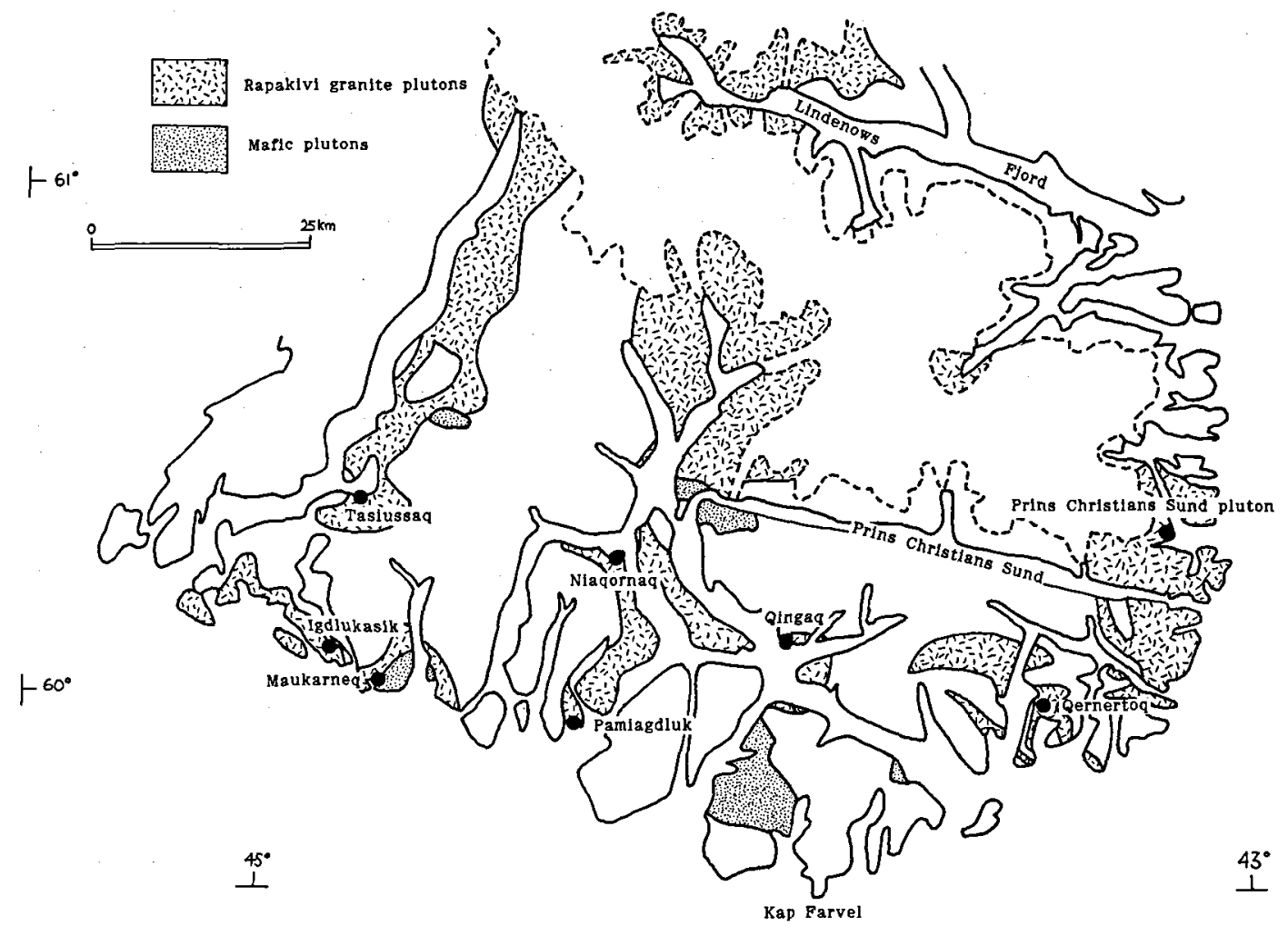

Fig. 1. Simplified geological map of the rapakivi suite intrusives in Southern Greenland, showing the known localities for magma mingling and mixing. Boundaries based upon available 1:500,000 geological map and re-mapping by project members. Boundary of ice marked by dashed line.

The mixed magma rocks which are cut by the synplutonic dykes cover an area of over $3 \mathrm{~km}^{2}$ and are characterised by large globular masses of medium-grained porphyritic micro-rapakivi granite enclosed in the coarse black rapakivi granite that forms the rest of the pluton. These masses are usually between 5 and $10 \mathrm{~m}$ in diameter, (some up to $30 \mathrm{~m}$ ) and form approximately $50 \%$ of the outcrop area. The margins of the masses may either be sharp or gradational, and there is a large amount of mixing between the two types. The outer margin of the mixed magma zone is quite sharply defined, and can be placed to within $3 \mathrm{~m}$.

The synplutonic dyke complex sharply crosscuts the mixed magma zone and the rapakivi granite that forms the rest of the pluton. The outer contacts of the composite dykes are aphyric basalts which have chilled against both the host rocks and the micro-rapakivi granite component in the interior of the dykes. The basalt show crenulate and globular contacts (fig. 2) which are interpreted as the result of strong contrasts on viscosity, temperature and density between the two magmas upon emplacement. Mediumgrained melanocratic micro-norites with prominent biotite phenocrysts are found in the interior of the composite dykes, and these may develop a strong dextral shear fabric. Although these sheared rocks are cut by the unsheared basaltic outer margins, they too display crenulate and globular chilled contacts, in this case with the porphyritic micro-rapakivi granite. In the interior of the dykes, porphyritic micro-rapakivi granite occurs as sharply defined sheets interlayered with the mafic material, and although the two rock types do not appear to have mixed, the porphyritic micro-rapakivi granite develops numerous rapakivi-textured K-feldspars at the interface with the basalt margin of the dyke. Despite the obvious dextral shearing in the mafic rocks from the centre of the composite intrusions, the porphyr- 
Fig. 2. Crenulate contact between chilled basalt margin of composite dyke and surrounding rapakivi granite. Prins

Christians Sund pluton. Hammer is $75 \mathrm{~cm}$ long.

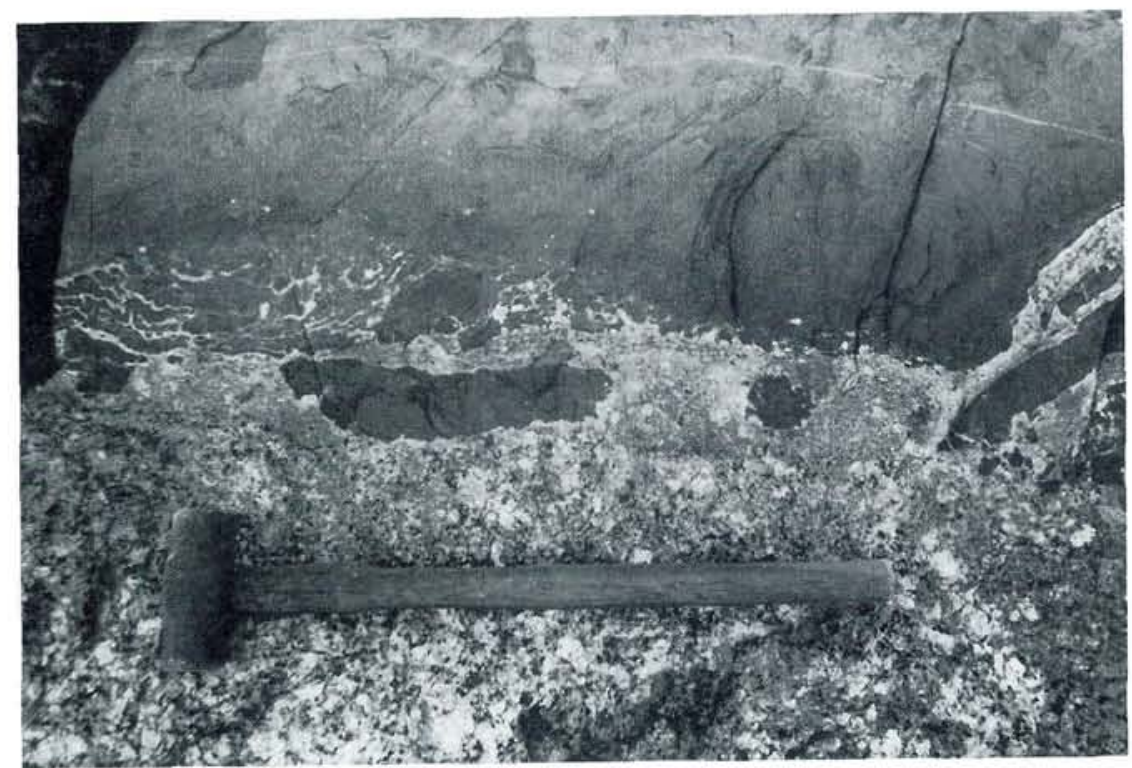

itic microgranite does not display any shear fabric, suggesting that it may have had a lower viscosity than the mafic rocks. This difference may have occurred in response to the chilling of the mafic magma against the granitic magma, reducing the viscosity of the former enabling non-melt hosted deformation to take place.

The synplutonic dyke complex was intruded into a dextral shear zone and several generations of composite dyke can be recognised within the complex on the basis of the amount of deformation they display. Early dykes were emplaced when the surrounding granite was relatively ductile, and the shearing event resulted in the boudinage and rotation of the dykes (fig. 3). As the rapakivi granite solidified, it became less able to accomodate the shearing through melt-hosted deformation and the dykes themselves started to accomodate strain by deforming. This is seen in the field as sheared 'tails' to the boudinaged
Fig. 3. Boudinaged and rotated mafic dyke. Location of Fig. 2 is behind the figure.

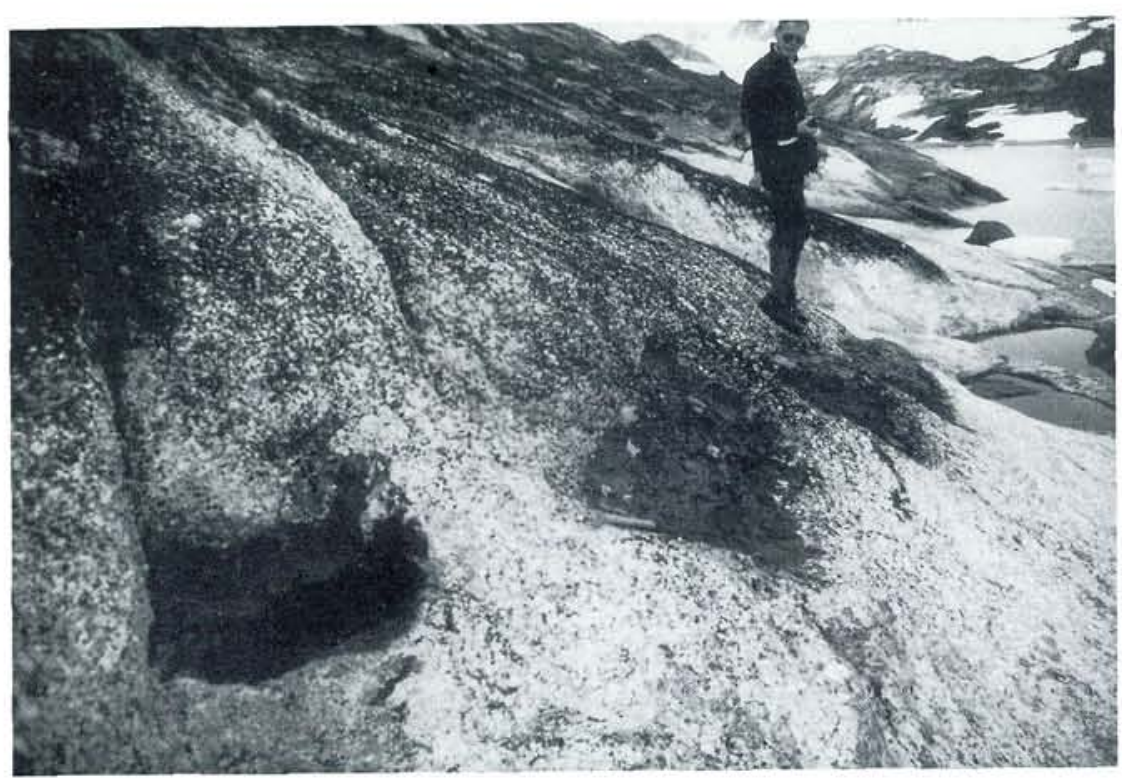




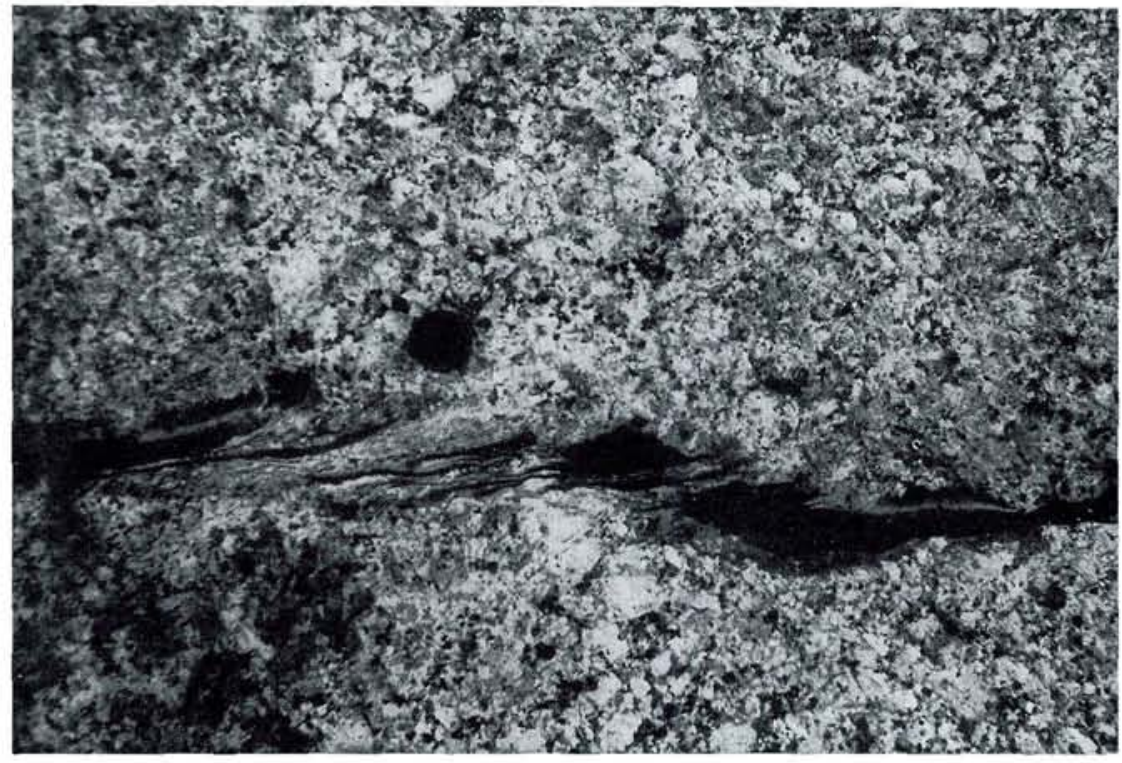

Fig. 4. Sheared tail to boudinaged mafic dyke, Prins Christians Sund pluton. Lens cap for scale.

mafic dykes (fig. 4), the interior of the dykes remaining largely undeformed. In the latter stages of deformation the entire dyke develops a strong dextral fabric (fig. 5). Unfortunately, as none of the dykes actually cross-cut each other, exact age relations can only be assumed on the basis of the degree of deformation.

\section{Other synplutonic mafic intrusions}

Whilst synplutonic dykes have only been noted from the one locality described above plug-like synplutonic mafic intrusions are more common, having been noted from many localities (shown in fig. 1). They all show several common features: a) highly variable nature of contacts between felsic and mafic material, where crenulate, globular contacts can be found only a matter of metres

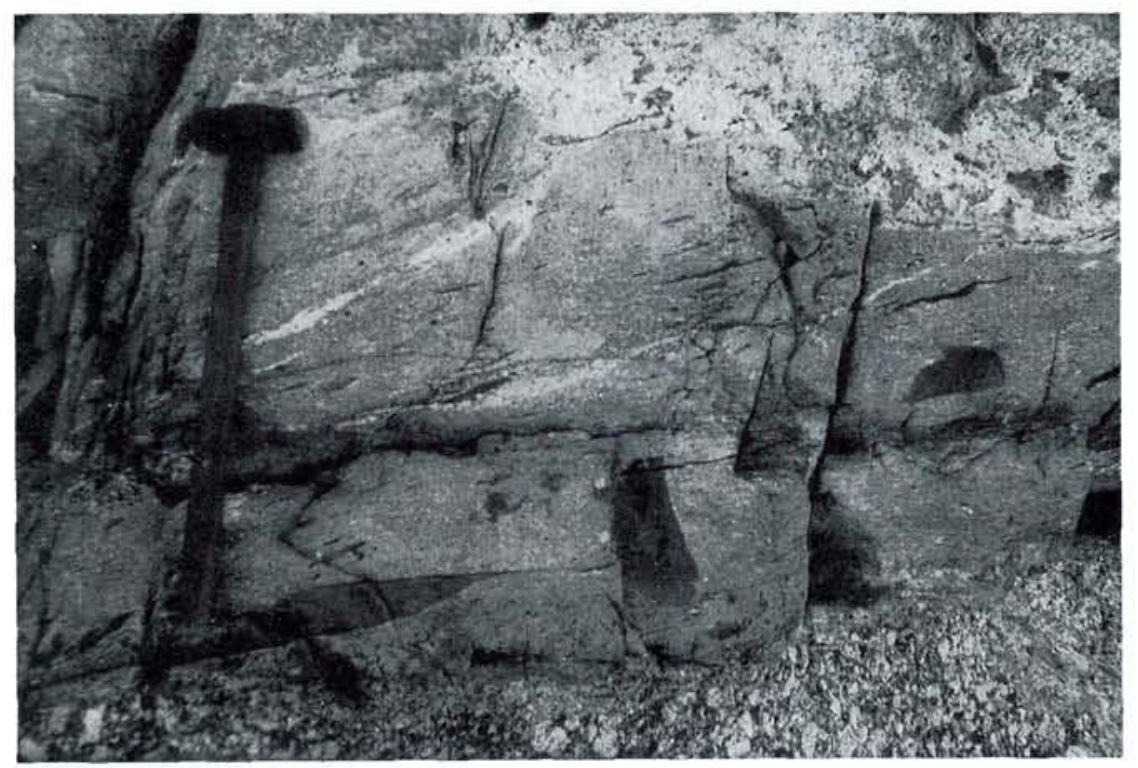

Fig. 5. Dextrally sheared composite dyke, Prins Christians Sund pluton. 
away from the angular, veined and rectilinear contacts; b) internal inhomogeneity, both of grain-size (reflecting in part the chilling of the mafic magma against its host) and of mineralogy (reflecting localised hydrothermal alteration and variable growth of K-feldspar ovoids, many of which develop rapakivi texture). The distribution of mantled K-feldspar ovoids can also be highly irregular in the surrounding granite. For example, the rapakivi granite surrounding a plug in Tasiussaq shows an increase in both the number and the size of the ovoids in the granite, and at their extreme development the ovoids reach $7-8 \mathrm{~cm}$ in diameter and have plagioclase mantles 5-10 $\mathrm{mm}$ thick. Coarse-grained biotiote (up to $1.5 \mathrm{~cm}$ across) accompanies these large ovoids which suggests that volatile-rich (pegmatitic) conditions may have prevailed during crystallisation; small veins of quartz-feldspar pegmatite also cut the mafic body. In addition, one of the mafic bodies in the Igdlukasik area develops fine-scale rhythmic layering of pyroxene and plagioclase.

\section{Discussion}

The co-existence of felsic and mafic melts is a well-documented phenomenon in both volcanic and plutonic settings (Walker and Skelhorn 1966; Marshall and Sparks 1984), and may manifest itself in many forms. Rounded mafic inclusions are common in many granitic rocks (Didier 1973) and it has been suggested that these represent either restite (White and Chappel 1977), immiscible liquids (Bender et al. 1982), or quenched mafic melts (Vernon 1983, 1984). Recent isotopic (Holden et al. 1987) and chemical (Frost and Mahood 1987) studies argue strongly in favour of the latter interpretation.

The mixing of mafic with felsic magmas to form large amounts of hybid magma can occur if the temperature differences are low, if convection and other chemical diffusive processes are effective (Huppert et al. 1984), or if the mass fractions of the two magma types are similar.

Conversely, the mingling of mafic and felsic magmas may occur when either the temperature difference between the two magmas is high, viscosity difference is high, homogenising processes are not effective (e.g., poor convection, low diffusion rates, etc.) or when the mass fractions of the two magmas are significantly different (e.g., Frost and Mahood, 1987). Mingling processes cannot, therefore, be expected to produce large amounts of hybrid magma. In a felsic plutonic environment, the injection of mafic magma at a late stage in pluton development may result in the formation of a synplutonic dyke complex (Roddick and Armstrong 1959; Pitcher et al. 1985).

The significance of mafic magmatism contemporaneous with large-scale felsic magmatism has become clear in recent studies (Hildreth 1981; Pitcher et al. 1985). It is now apparent that in most granite (sensu lato) generating events, the continued input of heat into the base of the continental crust through the emplacement of mafic magma is essential for continued magmatism (Huppert and Sparks 1988).

In the early stages of granite magma generation, large-scale mixing of felsic (granitic) and mafic components is inevitable, but as the volume of felsic magma increases and starts to rise through the crust further mixing with mafic magma on such large scale becomes increasingly unlikely. Of all the constraints upon mixing noted above, mass fraction and viscosity difference appear to be the most important (e.g., Frost and Mahood, 1987).

The preservation of such small amounts of contemporaneous mafic magmatism as are seen in the South Greenland rapakivi granites yields important information about the rheological properties of the magmas. The mixing of magmas in a plutonic environment will, provided the prerequisite conditions are met, be controlled by mechanical diffusive processes such as convection. This process in turn is dependent upon the viscosity of the magma, and in a large partially crystalline felsic magma body macro-scale convection is inevitable until crystallisation increases the viscosity to approximately $10^{10}$ poise, equivalent to a crystal content of $65-70 \%$ (van der Molen and Paterson 1979). Beyond this value the magma behaves essentially as crystalline solid. Furman and Spera (1985) have shown that convective mixing in a felsic pluton will effectively eradicate any trace of newly injected mafic magma for up to $10^{4}$ years after the emplacement of that pluton. As crystallisation increases the viscosity of the host granite magma, any further inputs of mafic magma wil be intruded into a 
progessively more crystalline host, and reduced convection in this host will lessen the inevitability of the wholesale disruption of synplutonic mafic intrusions.

For the preservation of the synplutonic intrusions seen in the rapakivi granites a crystal content of at least $60 \%$ is required. Concerning the magma mixing zone in the Prins Christians Sund pluton, field observations show that the mass fractions of the granitic and noritic magmas were similar, and that some of the noritic "blobs" have discrete contacts with their host. This suggests that in the exposures studied mass fraction controlled the degree to which the two magma types mixed, that the viscosity of the host was in the order of $10^{9}$ poise (equivalent to a crystal content of approximately $60 \%$ ), and that macro-scale convective mixing was not an effective process.

\section{Dansk sammendrag}

De tidligt proterozoiske rapakivi graniter $\mathbf{i}$ Sydgrønland har ofte partier af synplutoniske mafiske intrusioner i form af dykekomplekser og små plug-lignende legemer. De mafiske intrusioner viser ofte smăfoldede (krenulerede) afkølingskontakter mod den granitiske værtsbjergart og der er en meget ringe grad af opblanding mellem de to magmatyper. Årsagen til den ringe grad af opblanding må søges i magmaernes høje viskositet og i markante kontraster mellem de to magmaer hvad angår temperatur og massefylde; dette selvom de to bjergartstyper forekommer nogenlunde lige stor mangde. Mere end $60 \%$ af det granitiske magma bestod på tidspunktet for indtrængningen af de mafiske intrusioner af krystaller, hvilket er en årsag til, at konvektionsbetinget blanding af de to magmaer var forsvindende lille.

\section{Acknowledgments}

The work presented here is based upon field observations made in 1987 by P. E. B. and 1988 by T. N. H., A. A. F., and R. J. R. The project is supported by N. E. R. C. grant GR3/6336. D. Bridgwater is thanked for his helpful comments.

\section{References}

Allaart, J. H. 1976: Ketilidian mobile belt in South Greenland. In Escher, A. and Watt, W. S. (eds.): Geology of Greenland. Grønlands Geologiske Undersøgelse: Denmark, pp. 120-151.
Bender, J. F., Hanson, G. F. \& Bence, A. E. 1982: The Cortlandt complex: evidence for large-scale liquid immiscibility involving granodiorite and diorite magmas. Earth Planet. Sci. Lett. 58, 330-344.

Bridgwater, D. 1963: A review of the Sydprøven granite and other "New Granites" of South Greenland. Medd. Dansk Geol. Foren. 15, 167-182.

Bridgwater, D., Sutton, J. \& Watterson, J. 1974: Crustal downfolding associated with igneous activity. Tectonophys. 21 , $57-77$.

Didier, J. 1973: Granites and their enclaves. Elsevier, Amsterdam. $393 \mathrm{pp}$.

Frost, T. P. \& Mahood, G. A. 1987: Field, chemical, and physical constraints on mafic-felsic magma interaction in the Lamarck Granodiorite, Sierra Nevada, California. Bull. Geol. Soc. Am. 99, 272-291.

Furman, T. \& Spera, F. J. 1985: Co-mingling of acid and basic magma with implications for the origin of mafic I-type xenoliths: Field and petrochemical relations of an unusual dyke complex at Eagle Lake, Sequoia National Park, California, U.S.A. J. Volc. Geotherm. Res. 24, 151-178.

Hildreth, W. 1981: Gradients in silicic magma chambers: implications for lithospheric magmatism. J. Geophys. Res. 86, 10153-10192.

Holden, P., Halliday, A. N. \& Stephens, W. E. 1987: Neodymium and strontium isotope content of microdiorite enclaves points to mantle input to granitoid production. $\mathrm{Na}$ ture 53-56.

Huppert, H. E. \& Sparks, R. S. J. 1988: The generation of granitic magmas by intrusion of basalt into continental crust. J. Petrol. 29, 599-624.

Huppert, H. E., Turner, J. S. \& Sparks, R. S. J. 1984: Some effects of viscosity on the dynamics of replenished magma chambers. J. Geophys. Res. 89, 6857-6877.

Hutton, D. H. W., Dempster, T. J. \& Brown, P. E. (in prep.): A new mechanism of granite emplacement: rapakivi intrusions in the active extensional shear zones.

Marshall, L. A. \& Sparks, R. S. J. 1984: Origin of some mixed-magma and net-veined ring intrusions. J. Geol. Soc. Lond. 141, 171-182.

Pitcher, W. S., Atherton, M. P., Cobbing, E. J. \& Beckinsale, R. D. 1985: Magmatism at a plate edge: the Peruvian Andes. Blackie, Glasgow. 328 pp.

Roddick, J. A. \& Armstrong, J. E. 1959: Relict dykes in the Coast Mountains near Vancouver, B.C. J. Geol. 67, 603613.

van der Molen I. \& Paterson, M. S. 1979: Experimental deformation of partially melted granite. Contrib. Mineral. Petrol. 70, 299-318.

Vernon, R. H. 1983: Restite, xenoliths and microgranitoid enclaves in granites. J. Proc. soc. New South Wales 116, 77-103.

Vernon, R. H. 1984: Microgranitoid enclaves in granites globules of hybrid magma quenched in a plutonic environment. Nature 309, 438-39.

Walker, G. P. L. \& Skelhorn, R. R. 1966: Some associations of acid and basic igneous rocks. Earth Sci. Rev. 2, 95-109.

White, A. J. R. \& Chappel, B. W. 1977: Ultrametamorphism and granitoid genesis. Tectonophys. 43, 7-22. 